DE

DE GRUYTER

OPEN

U

10.1515/topling-2017-0004

\title{
Modal adverbs of certainty in the rhetoric of Advocates General: a dialogic view
}

\author{
Magdalena Szczyrbak \\ Jagiellonian University, Poland
}

\begin{abstract}
The article deals with EU judicial rhetoric and aims to demonstrate how a selection of modal adverbs of certainty (indeed, clearly, (not) necessarily and of course) are used in the Opinions of the Advocates General at the European Court of Justice (ECJ). To this end, it focuses on the rhetorical functions of these adverbs, such as adding emphasis, showing a high degree of commitment and backgrounding alternative viewpoints. The study applies the notions of stance and engagement (Hyland, 2005) and builds on the research into modal adverbs of certainty reported in Simon-Vandenbergen and Aijmer (2007). In summary, the analysis sheds light on the rhetorical potential of modal adverbs, stressing the dialogic dimension of legal opinion writing.
\end{abstract}

\section{Key words}

Advocates General, EU legal discourse, engagement, judicial rhetoric, modal adverbs, stance

\section{Introduction'}

Despite the wealth of publications which approach modality from various angles, there are still many unexplored aspects which can provide new insights and, eventually, lead to a re-contextualization of this linguistic phenomenon. The use of modal adverbs of certainty in legal opinion writing seems to be an under-researched area and therefore calls for a more thorough treatment. Thus, the goal of this paper is, on the one hand, to highlight the dialogic orientation of legal opinion writing and, on the other hand, to demonstrate the rhetorical usefulness of a selection of modal adverbs which, it is argued, index some degree of dialogicity and are used not only to express the writer's attitude to

\footnotetext{
1 The article uses material from the talk "Modal adverbs of certainty in lawyers' rhetoric at the European Court of Justice" delivered on 10 October 2013 at the conference Rhetorik in Europa: Konvergenz und Divergenz organized by the European Institute of Rhetoric at Saarland University, Saarbrücken, Germany. The material has been reworked and extended.
}

knowledge, but also to position his or her arguments against alternative viewpoints.

1. A dynamic approach to modal adverbs Epistemic or modal adverbs can be found within the various classifications of adverbs proposed in grammar books (see, e.g., Biber, et al., 1999). However, these accounts seem to overlook the distinction between the semantic and pragmatic meanings of modal adverbs, which, as White (2003) argues, are used for a number of reasons beyond those related to the assessment of the speaker's or the hearer's knowledge. The importance of such a distinction is underlined by SimonVandenbergen and Aijmer (2007, pp. 4-5), who adopt an interactive approach to modal adverbs of certainty, interpreting their use, especially in argumentative discourse, in the context of other utterances, both real and imagined. As Simon-Vandenbergen and Aijmer (2007, p. $41)$ state, "[t]he rhetorical function or effect of an adverb of certainty is to signal that an utterance presents a stronger argument 
than an alternative one." Therefore they hold that speakers use adverbs expressing a high degree of certainty in order to position themselves towards other discourse participants or other voices (Simon-Vandenbergen and Aijmer, 2007, p. 33) as well as to influence the hearer's attitudes, beliefs or expectations.

Drawing on Chafe's (1986) classification of evidentials, Simon-Vandenbergen and Aijmer (2007, p. 84) group adverbs of certainty into four clusters: 1) epistemic adverbs; 2) evidential adverbs; 3) expectation adverbs, and 4) speech act adverbs. Adverbs in the first category (e.g. certainly, definitely, indeed, no doubt, undoubtedly, surely) express the speaker's high degree of commitment to the truth of the proposition, whereas adverbs found in the second group (e.g. obviously, clearly, plainly, evidently, manifestly) express certainty based on evidence. The third cluster, in turn, includes adverbs (e.g. of course, naturally, inevitably, necessarily) whose "core meaning of certainty is based on the fact that the state of affairs is in accordance with expectations" (SimonVandenbergen and Aijmer, 2007, p. 84). Finally, the fourth group of adverbs (e.g. admittedly, undeniably, indisputably, arguably) includes those which express certitude "through conveying explicitly that the speaker's viewpoint is to be seen in the light of alternative voices" (SimonVandenbergen and Aijmer, 2007, p. 84). Yet, as the authors admit, since adverbs tend to be multifunctional, the proposed classification serves merely as a starting point and it may be the case that an analyst will have to assign particular adverbs to several classes (Simon-Vandenbergen and Aijmer, 2007, p. 83). ${ }^{2}$

\section{Aims, method and data}

The study reported here focuses on the rhetorical ${ }^{3}$ usefulness of modal adverbs of certainty in legal opinion writing. More specifically, attention is drawn to the linguistic preferences of the Advocates General at the ECJ, and an explanation of their possible pragmatic motivation is

\footnotetext{
2 This is in agreement with prototype theory, advocated by cognitive linguists (see, e.g., Geeraerts, 2006).

3 In this article, the word "rhetorical" is used to describe language resources which fulfil interpersonal functions (cf. Schwenter and Traugott, 2000) and which speakers/writers deploy to orient themselves towards other speakers/writers and their respective standpoints.
}

offered. The study also seeks to reveal the multifunctionality of the adverbs selected, resulting from their deployment in the argumentation stage of the Opinions, on the one hand, and on the other their position within specific text segments and co-occurrence patterns.

Methodologically, the research is situated within discourse-analytic studies of judicial rhetoric and it adopts the broad notion of dialogism. The latter subsumes, for instance, the concepts of polyphony (Anscombe and Ducrot, 1983), heteroglossia (Bakhtin, 1981), and stance and engagement (Hyland, 2005). ${ }^{4}$ Of these, Hyland's (2005) model of stance and engagement (originally applied in studies of academic texts) appears to be most relevant to the current analysis. In this approach, stance refers to the ways "writers present themselves and convey their judgements, opinions, and commitments" as well as how they "stamp their personal authority onto their arguments," whereas engagement denotes the features through which writers recognize the presence of their readers, focus their attention, and guide them to particular interpretations (Hyland 2005, p. 176). The study also draws on the discourse-pragmatic model of Concession proposed by Couper-Kuhlen and Thompson (2000) and developed by Barth-Weingarten (2003), in which Concession is defined as a sequence of (implied) claims, acknowledgments and counterclaims, all of which may appear in a variety of configurations.

The dataset used for analysis comprised 30 Opinions delivered in the period of March 2011 to March 2013.5 Although the whole corpus consists of approximately 250,000 words, the analysis was based on a subcorpus totaling 145,000 words, composed of the persuasive argumentation stage of the Opinions. At this point, it should be added that the Advocates General can write their Opinions in any of the official languages of the EU. Therefore, since only those Opinions originally written in English were used to compile the corpus, the number of authors was limited. Consequently, texts written by four

\footnotetext{
${ }^{4}$ For a discussion of dialogic approaches to discourse, see also Emondson (2014) and Fetzer (2014).

5 The Opinions were downloaded from

http://curia.europa.eu/jurisp/cgi-bin/form.pl?lang=en (date of access: 10 May 2013).
} 
Advocates General (British, Finnish, Slovak and Portuguese) were used. ${ }^{6}$

It should, too, be noted that the Advocates General present Opinions on the cases to which they are assigned and that they deliver their Opinions (which, however, are not binding for the ECJ) only if the ECJ believes that a given case raises a new point of law. As to their communicative purpose, Opinions serve primarily "to persuade the Court that the solution proposed is well founded from a legal point of view and [that] the court's rulings should be based on it," and, further, "to persuade the litigants that the rulings of the Court which follow are based on a thoroughly and justly argued legal Opinion, and therefore, are the right decisions" (Salmi-Tolonen (2005, p. 66).

Since the primary function of the Opinions is that of persuasive argumentation rather than the prescription of a certain course of action, the Advocates General present their views, accepting or rejecting the claims advanced by the litigant parties in the previous phases of the legal process (Salmi-Tolonen, 2005, p. 61). Typically, such argumentation involves the following stages (adapted from SalmiTolonen, 2005, p. 91): "Recognizing the rule," "Interpreting the contents," "Institutional support," and "Persuasive argumentation" (Table 1).

\begin{tabular}{|l|l|l|}
\hline \multicolumn{1}{|c|}{$\begin{array}{c}\text { Role in } \\
\text { argumentation }\end{array}$} & $\begin{array}{l}\text { Propositional } \\
\text { content }\end{array}$ & $\begin{array}{c}\text { Author } \\
\text { visibility }\end{array}$ \\
\hline $\begin{array}{l}\text { Recognizing the } \\
\text { rule }\end{array}$ & $\begin{array}{l}\text { Object and the } \\
\text { type of case; } \\
\text { Definition of } \\
\text { the legal } \\
\text { domain }\end{array}$ & Implicit \\
\hline $\begin{array}{l}\text { Interpreting the } \\
\text { contents }\end{array}$ & $\begin{array}{l}\text { Reference to } \\
\text { precedents; } \\
\text { Metatext } \\
\text { describing the } \\
\text { content of the } \\
\text { Opinion }\end{array}$ & (Explicit) \\
\hline $\begin{array}{l}\text { Institutional } \\
\text { support }\end{array}$ & $\begin{array}{l}\text { Legal and } \\
\text { factual context } \\
\text { (legislation and } \\
\text { case law, } \\
\text { legislative } \\
\text { antecedents); } \\
\text { Written } \\
\text { observations of } \\
\text { the parties }\end{array}$ & \\
\hline
\end{tabular}

6 Therefore, the data analyzed here represent both native and non-native discourse. However, as explained later in the article, the distribution of the selected adverbs in native vs. non-native discourse in the Opinions analyzed does not indicate any generalizable trends. As such, it seems to have little relevance in the context of the current study.

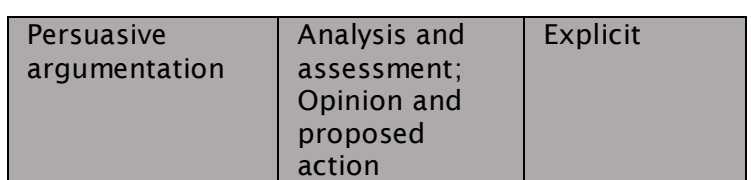

Table 1: Argumentation process in the Opinions

To examine the role of modal adverbs of certainty in judicial reasoning, the "Persuasive argumentation" stage of the Opinions was selected for analysis. The results are reported in Section 3.

\section{Analysis}

As noted above, the analysis covered the last stage of the Opinions, in which case author visibility was explicit. At the outset, following Simon-Vandenbergen and Aijmer's (2007) classification, I identified the most common modal adverbs in the data. Of a total of 205 adverbs, the following were the most commonly employed: indeed (59 tokens), clearly (56 tokens), (not) necessarily (25 tokens) and of course (13 tokens), as shown in Table 2. The two most frequent adverbs, that is indeed and clearly, represented the categories of epistemic and evidential adverbs, respectively, while the least frequently employed adverbs (e.g. undoubtedly, unquestionably) belonged to the class of speech act adverbs.

\begin{tabular}{|l|l|c|c|}
\hline \multicolumn{1}{|c|}{$\begin{array}{c}\text { Modal } \\
\text { adverb } \\
\text { of } \\
\text { certainty }\end{array}$} & Category & $\begin{array}{c}\text { Raw } \\
\text { count }\end{array}$ & $\begin{array}{c}\text { Normed } \\
\text { score } \\
\text { (freq. per } \\
\text { million } \\
\text { words) }\end{array}$ \\
\hline indeed & $\begin{array}{l}\text { Epistemic } \\
\text { adverb }\end{array}$ & 59 & $\mathbf{( 4 0 6 )}$ \\
\hline clearly & $\begin{array}{l}\text { Evidential } \\
\text { adverb }\end{array}$ & 56 & $\mathbf{( 3 8 6 )}$ \\
\hline $\begin{array}{l}\text { (not) } \\
\text { necessarily }\end{array}$ & $\begin{array}{l}\text { Expectation } \\
\text { adverb }\end{array}$ & 25 & $\mathbf{( 1 7 2 )}$ \\
\hline of course & $\begin{array}{l}\text { Expectation } \\
\text { adverb }\end{array}$ & 13 & $\mathbf{( 8 9 )}$ \\
\hline apparently & $\begin{array}{l}\text { Evidential } \\
\text { adverb }\end{array}$ & 8 & $(55)$ \\
\hline manifestly & $\begin{array}{l}\text { Evidential } \\
\text { adverb }\end{array}$ & 8 & $(55)$ \\
\hline plainly & $\begin{array}{l}\text { Evidential } \\
\text { adverb }\end{array}$ & 6 & $(41)$ \\
\hline admittedly & $\begin{array}{l}\text { Speech act } \\
\text { adverb }\end{array}$ & 5 & $(34)$ \\
\hline certainly & $\begin{array}{l}\text { Epistemic } \\
\text { adverb }\end{array}$ & 5 & $(34)$ \\
\hline
\end{tabular}

7 To put the figures in perspective, the epistemic
modal verbs may and might had 220 and 60 modal verbs may and
occurrences, respectively. 


\begin{tabular}{|l|l|c|c|}
\hline obviously & $\begin{array}{l}\text { Evidential } \\
\text { adverb }\end{array}$ & 5 & $(34)$ \\
\hline arguably & $\begin{array}{l}\text { Speech act } \\
\text { adverb }\end{array}$ & 4 & $(27)$ \\
\hline definitely & $\begin{array}{l}\text { Epistemic } \\
\text { adverb }\end{array}$ & 4 & $(27)$ \\
\hline inevitably & $\begin{array}{l}\text { Expectation } \\
\text { adverb }\end{array}$ & 3 & $(20)$ \\
\hline undoubtedly & $\begin{array}{l}\text { Epistemic } \\
\text { adverb }\end{array}$ & 2 & $(13)$ \\
\hline unquestionably & $\begin{array}{l}\text { Speech act } \\
\text { adverb }\end{array}$ & 2 & (13) \\
\hline
\end{tabular}

Table 2: Modal adverbs of certainty in the data

As for the distribution of the most common modal adverbs in native vs. non-native discourse (Table 3), it was observed that clearly, (not) necessarily and of course were more frequent in native discourse than in non-native discourse. Indeed, on the other hand, seemed to be favoured in non-native discourse. However, since the range of the data analyzed is limited (as is the number of authors), the figures obtained do not permit any valid generalizations about preferences in the use of modal adverbs by Advocates General who are native and non-native speakers of English. Therefore, these differences are not accounted for in the ensuing analysis. Rather, it is the relevance of the selected adverbs to judicial reasoning that is highlighted.

\begin{tabular}{|c|c|c|c|c|}
\hline \multirow[t]{2}{*}{$\begin{array}{l}\text { Modal } \\
\text { adverb } \\
\text { of } \\
\text { certainty }\end{array}$} & \multicolumn{2}{|c|}{$\begin{array}{c}\text { Native } \\
\text { discourse } \\
\text { (app. 62,500 } \\
\text { words) }\end{array}$} & \multicolumn{2}{|c|}{$\begin{array}{c}\text { Non-native } \\
\text { discourse } \\
\text { (app. } 81,800 \\
\text { words) }\end{array}$} \\
\hline & $\begin{array}{l}\text { Raw } \\
\text { count }\end{array}$ & $\begin{array}{c}\text { Normed } \\
\text { score } \\
\text { (freq. } \\
\text { per } \\
\text { million } \\
\text { words) }\end{array}$ & $\begin{array}{l}\text { Raw } \\
\text { count }\end{array}$ & $\begin{array}{l}\text { Normed } \\
\text { score } \\
\text { (freq. } \\
\text { per } \\
\text { million } \\
\text { words) } \\
\end{array}$ \\
\hline indeed & 21 & (336) & 38 & (464) \\
\hline clearly & 30 & $(480)$ & 26 & (317) \\
\hline $\begin{array}{l}\text { (not) } \\
\text { necessarily }\end{array}$ & 16 & (256) & 9 & $\left(\begin{array}{lll}1 & 1 & 0\end{array}\right)$ \\
\hline of course & 8 & (128) & 5 & (61) \\
\hline
\end{tabular}

Table 3: The most frequent modal adverbs of certainty in native vs. non-native discourse
In the following subsections, the role of the most frequently employed modal adverbs (i.e. indeed, clearly, (not) necessarily and of course) in the argumentation stage of all the Opinions in the corpus is discussed. Their characteristics, as reported in other studies, are also briefly provided.

\subsection{Indeed}

It might first be observed that indeed, representing the category of epistemic adverbs, is found chiefly in more formal genres (e.g. parliamentary debates, nonbroadcast speeches, and academic writing in the humanities) and that it is rather infrequent in conversation. ${ }^{8}$ Functionally, indeed is "linked to epistemic stance and can be used to take up positions to what is said, to the hearer, to assumptions which are attributed to the hearer or to people in general" (Aijmer, 2007, p. 330). It is also noteworthy that indeed is associated with persuasive, argumentative discourse and, perhaps more importantly, that it indexes the speaker's authority, conveying as it does both confidence and power (SimonVandenbergen and Aijmer, 2007, p. 216).

Not surprisingly then, with 59 tokens, indeed was identified as the most frequently employed certainty adverb in the corpus, occurring in two clearly identifiable patterns. The first of these, the $A$ and indeed $B$ schema, incorporating a rhetorical addition, marked emphasis. For instance, and taking the points which follow as examples, in (1) and (2) and indeed is deployed to add an element which is more important and thus rhetorically stronger (cf. Simon-Vandenbergen and Aijmer, 2007 , p. 107). To be specific, in (1) "required" is more forceful than "entitled," while in (2) the Advocate General stresses that the finding in question not only "must be read", but that it, in fact, "reveals" its true meaning when interpreted in conjunction with Art. 13(1). In both contexts, when used to add new evidence, indeed could be replaced by "furthermore."

(1) I would point out, however, that the main proceedings concern the acquisition and installation of solar panels in 2005, at which time taxable

\footnotetext{
8 As reported by Simon-Vandenbergen and Aijmer (2007, p. 201), the frequency of indeed in parliamentary debates is 850 tokens per million words, while in the case of direct conversations the figure stands at 61 .
} 
persons were entitled (and indeed required) to allocate capital goods as between the private and business spheres [...] [0-1]

(2) That finding, implying that it is permissible to grant such a benefit, must be read - and indeed reveals its meaning - against the background of the principle enshrined in Article 13(1) of Regulation No 1408/71, mentioned above, (23) under which [...] [0-26]

The second recurrent pattern involving the use of indeed was the Yes, but Concessive $^{9}$ schema, where indeed was used as a marker of (at least partial) agreement cueing the acknowledging move $\left(\mathrm{X}^{\prime}\right) .{ }^{10}$ In (3), for instance, where indeed is used in combination with the emphatic do, the Advocate General confronts the absentee opponent and, as phrased by Aijmer (2007: 340), "takes up a stance to the preceding discourse for rhetorical purposes in order to later reject the argument." In other words, by foregrounding and backgrounding selected arguments in Concessive sequences, indeed serves to concede a minor point in order to advance a major argument." More precisely, while in (3) the Advocate General admits that the German court's interpretation interferes with the right to property guaranteed by the Charter of Fundamental Rights (acknowledgment), this interference is, in his view, admissible in light of Art. 17(1), if certain conditions are met (counterclaim). Thus, while admitting partial validity of the claim made by the litigant ("while it does indeed interfere"), the Advocate General argues that, as she believes, the interference is justified and thus permissible ("such

\footnotetext{
9 Whenever capitalized, the adjective "Concessive" refers to the discourse-pragmatic notion of Concession. The use of the lower-case "concessive," on the other hand, refers to the semantic-syntactic (interclausal) relation.

10 In the discourse-pragmatic approach to Concession, 0 stands for implied claim (which can be inferred from context), X stands for claim, X' for acknowledgment, $Y$ for counterclaim and $Y^{\prime}$ for return to counterclaim. 11 It might be added that the rhetorical potential of concessio, i.e. the strategy of "agreeing in order to disagree," was recognized by ancient rhetoricians, with Quintilian claiming that "by restricting his claims, by giving up certain theses or arguments, a speaker can strengthen his position and make it easier to defend" (1921-1933, p. 488 cited in Couper-Kuhlen and Thompson, 2000, p. 383).
}

interference is in my view clearly permitted"). Another thing to note is the co-occurrence of concessive and contrastive markers: the backgrounded argument (acknowledgment) is cued by the concessive while, the emphatic do, and indeed, whereas the foregrounded argument (counterclaim) is marked by the contrastive however, and the stance markers in my view and clearly.

(3) $[X]$ First, Fujitsu and Hewlett Packard argue that the Bundesgerichtshof's interpretation interferes with the right to property guaranteed by Article 17 of the Charter of Fundamental Rights, (61) in that it prevents rightholders from granting free licences to copy their works. [CLAIM]

[X'] However, while it does indeed interfere with that right, [ACKNOWLEDGMENT]

[Y] such interference is in my view clearly permitted by the second sentence of Article 17(1) of the Charter, in so far as it is 'in the public interest and in the cases and under the conditions provided for by law' and fair compensation is paid. [COUNTERCLAIM] [O-6]

That said, it may be posited that, being an "arguing word" (Aijmer, 2007, p. 332), indeed is a useful linguistic device which helps legal professionals to convey power and assert authority as well as to show rhetorical engagement in the (mute) dialogue with the litigant parties.

\subsection{Clearly}

The second most frequently employed adverb in the corpus, namely clearly, was attested by 56 tokens. As SimonVandenbergen and Aijmer (2007, pp. 201203) report, this evidential adverb is most common in legal cross-examinations and business transactions. ${ }^{12}$ They also note (Simon-Vandenbergen and Aijmer (2007, p. 199) that clearly is linked to intellectual reasoning, rather than interpersonal negotiation. As such, it differs, for instance, from obviously, which, though

\footnotetext{
12 In Simon-Vandenbergen and Aijmer's data (2007, p. $201)$, the frequency of clearly in legal crossexaminations is 300 tokens per million words and in business transactions - 250 tokens per million words. By contrast, in direct conversations the figure stands at 6 occurrences per million words.
} 
seemingly synonymous, has come to perform interactional functions in conveying solidarity (Simon-Vandenbergen and Aijmer, 2007, p. 199).

During the analysis it was found that in the Opinions, clearly was favored over obviously, with a frequency ratio of 56 to 5 tokens, respectively. Again, it can be argued that the Advocates General seem to prefer those linguistic devices which stress power and authority, rather than those linked to negotiation and solidarity. It is also fair to say that by analogy to indeed, clearly, which suggests tangible evidence, belongs to rational discussion and argumentation (Simon-Vandenbergen and Aijmer, 2007, p. 226). Consider for instance (4), where clearly operates as a sentence adverb in its initial position and where it can be paraphrased as "it is clear that." In this case, the Advocate General's statement is backed up by external evidence, as she claims that a situation in which "assistance has ceased within the meaning of the second sentence of Article $12(1)(a) "$ is the disputed "additional trigger."

(4) Consequently, since the exclusion must be presumed to have some actual effect, it cannot cease merely on departure from UNRWA's area of operation, regardless of the reason for the departure. There must be some additional trigger. Clearly, there is such a trigger when assistance has ceased within the meaning of the second sentence of Article 12(1)(a). [0-12]

In a similar vein, (5) demonstrates how clearly is used in logical reasoning to refer to solid evidence ${ }^{13}$ - i.e. the rules stipulated by the Sixth Directive - which serves to underline the Advocate General's judicial authority and to validate the proposed solution to the legal question being considered.

(5) At first sight, it would appear that so far the Court of Justice has been asked only once about the rule governing the treatment, pursuant to Article 5(7)(a) of the Sixth Directive, of certain transactions as supplies

\footnotetext{
${ }^{13}$ However, it might also be argued that in this instance clearly is an adverb of manner rather than a modal adverb reflecting the Advocate General's assessment of the available evidence.
}

for consideration: in Gemeente Leusden and Holin Groep. (14) In that judgment, however, the Court clearly focused on other rules laid down in the Sixth Directive. [0-14]

Finally, as with indeed, clearly appears to be favored by drafters of legal opinion, since it stresses accessible evidence and conviction based on logical reasoning.

\section{3 (Not) necessarily}

Decidedly less frequently employed than the two adverbs discussed above, (not) necessarily was attested by 25 tokens (including 17 tokens of necessarily and 8 of not necessarily). ${ }^{14}$ As for necessarily, it might first be observed that as an expectation adverb, it expresses the speaker's or writer's conviction regarding the inevitability of a certain state of affairs, it being a consequence of another state of affairs. However, as Simon-Vandenbergen and Aijmer observe, even though necessarily conveys deontic rather than epistemic necessity (2007, p. 188), its deontic and epistemic senses often cooccur $(2007$, p. 287). It should also be added that (not) necessarily (in contrast to the other adverbs examined in the current study) is never found in sentence-initial position, which suggests that even though (not) necessarily does express the speaker's stance, it has not progressed as far as the other adverbs "on the path towards epistemic markers" (SimonVandenbergen and Aijmer, 2007, p. 299). Instead, as Simon-Vandenbergen and Aijmer (2007, p. 299) hold, (not) necessarily - in a similar way to definitely is becoming more of a response marker with its own specific meaning.

Some of the above characteristics of (not) necessarily have been confirmed by the data analyzed in this study. For instance, the meaning of expectation resulting from external circumstances can be seen in (6). Here, the rhetorical effect of necessarily is enhanced by the presence of the adverb objectively, with the parallel structure necessarily and objectively being more emphatic than necessarily alone. Again, the Advocate General bases his argument on clearly verifiable evidence, namely "the difference in retirement age,"

\footnotetext{
14 In Simon-Vandenbergen and Aijmer's (2007) study, the distribution of (not) necessarily across different genres is not discussed.
} 
which must be accepted as the reason for the permitted derogation. A similar observation can be made with regard to (7), where the assessment being referred to follows from objective factors, such as the relevant legislation, or, more precisely, "Title II of Regulation No. 1408/71".

(6) The Court has held that 'where ... a Member State prescribes different retirement ages for men and women for the purposes of granting old-age and retirement pensions, the scope of the permitted derogation is limited to forms of discrimination which are necessarily and objectively linked to the difference in retirement age'. [O8]

(7) Such an assessment is necessarily based on the rules contained in Title II of Regulation No 1408/71 which concern the determination of the legislation applicable. [0-21]

The argumentative use of not necessarily, on the other hand, is illustrated by (8), where this negative adverb is used to deny something that appears to be a logical consequence. More specifically, according to the relevant regulations, fair compensation is due after a certain date, but it does not have to apply to events occurring prior to that date. The lack of "inevitable necessity" is additionally emphasized by the epistemic in principle, implying the Advocate General's agreement to the general idea but not the specific details concerning the case. In this instance, as noted earlier, the meanings of deontic and epistemic necessity conveyed by not necessarily seem to overlap.

(8) That means inter alia that, where a Member State has provided for an exception or limitation to the reproduction right in accordance with Article 5(2)(a) and/or (b) of the Directive, it is required to ensure that rightholders receive fair compensation in respect of relevant events after 22 December 2002 but, in principle, not necessarily before. [0-6]

As the above examples demonstrate, necessarily and (not) necessarily have their rhetorical strengths and are used to stress inevitable necessity or its absence, resulting from circumstances which are beyond the arguer's control and which, therefore, can be regarded as objective.

\subsection{Of course}

The last adverb to be discussed in this study is of course, an expectation adverb which is found mostly in demonstrations and broadcast interviews. ${ }^{15}$ In the data analyzed in the current study its frequency was relatively low (13 occurrences); however, I believe it still warrants attention.

Typically, of course is used to redress the power balance between interlocutors by playing down the speaker's superiority, a superiority which has resulted from the possession of knowledge (SimonVandenbergen and Aijmer, 2007, p. 205), and it fulfils face-saving functions as a politeness marker. Simon-Vandenbergen and Aijmer (2007, p. 30) also stress the concessive meaning of of course, likening it to although, and, at the same time, suggesting that it be interpreted as an equivalent of the presupposition "as everyone knows". Furthermore, like indeed, of course is found to cue acknowledgments in Concessive schemata; however, in contrast to the authoritative indeed, it tends to mark solidarity and equality. In certain contexts, it may, conversely, signal superiority of the arguer's knowledge, too.

Rather unsurprisingly, of all the uses of of course identified in the data, the concessive meaning stood out most clearly. The excerpt shown in (9) illustrates a Concessive sequence, where of course is used to background an alternative standpoint; namely, the assertion that the Italian Tribunal is able to reformulate the preliminary question submitted for consideration by the ECJ, so that it would no longer be purely hypothetical. Thus, it is especially useful for anticipatory rebuttal, ${ }^{16}$ with the arguer weaving into the argumentation a possible objection and refuting it in the return to the counterclaim, signaled with the contrastive marker however (counterclaim acknowledgment - return to the counterclaim schema). Therefore, whenever

\footnotetext{
15 Contrary to the findings reported here, in SimonVandenbergen and Aijmer's (2007, pp. 201-203) data, of course ranks as the most frequently employed adverb of certainty. Its frequency is highest in demonstrations (1,400 tokens per million words), broadcast interviews $(1,200$ tokens per million words), and non-broadcast speeches, including lectures $(1,150$ tokens per million words).

${ }_{16}$ Cf. the rhetorical figure of prolepsis.
} 
of course is found in the Yes, but pattern, it loses its strength as a certainty marker and it may be justifiably termed a "precursor of disagreement" instead (SimonVandenbergen and Aijmer, 2007, p. 303). ${ }^{17}$

(9) [Y] Nevertheless, in the present case I am inclined to conclude that the mismatch between the wording of the preliminary question on the one hand, and the texts of the national provision and the observations of the parties, on the other, render the preliminary reference of $a$ hypothetical character both in fact and in law. [COUNTERCLAIM]

[X'] It is, of course, open to the Court to simply leave it to the Commissione Tributaria Regionale di Milano to check the soundness of its initial interpretation of national law, after the Court has provided answers to the questions referred. [ACKNOWLEDGMENT]

[Y'] However, this may be insufficient to cure the hypothetical nature of the question. [RETURN TO COUNTERCLAIM] [0-16]

The concessive meaning aside, another context in which of course resurfaced in the corpus as a useful rhetorical device involved the presupposition of knowledge that is in some way taken for granted. Accordingly, the as-everybody-knows meaning of of course, used to state something which is assumed to be known both to the writer (here: the Advocate General) and the reader (here: the ECJ), can be seen in (10). In this paragraph, by inserting of course, the Advocate General expresses his conviction that the reasons for applying an imputation system to foreign-sourced dividends are obvious both to him and the ECJ (as they were already explained by another Advocate General) and that therefore they constitute a shared epistemic background.

(10) At this juncture it is necessary to make two observations. Firstly, the aim of applying an imputation system to foreign-sourced dividends is, of course, to achieve the effect

\footnotetext{
17 Were of course to appear in the counterclaim, however, it would boost the writer's preferred argument (as in the Yes, but of course schema), rather than serve to concede the opponent's claim (as in the Yes, of course, but pattern exemplified by [9]).
}

described by Advocate General Geelhoed, in other words, to eliminate the effect in the residence State taxation of a lower effective tax rate in the source State. [0-24]

Overall, the concessive function and the solidarity-orientation of of course merit attention and the argumentative potential of this adverb should not be overlooked in rhetorically-oriented analyses of judicial reasoning, either.

\section{Discussion}

As demonstrated in Section 3, two modal adverbs appear to be most salient in judicial argumentation, namely: indeed and clearly. To be precise, the normed frequency of indeed stood at 406 tokens per million words, while that of clearly was 386 tokens. This seems to agree with what Simon-Vandenbergen and Aijmer (2007, pp. 201-203) report about the distribution of indeed across text types, linking it to formal argumentative spoken genres such as parliamentary debates (with 850 tokens per million words) as well as formal argumentative writing, such as academic writing in the humanities and the social sciences (with 600 and 500 tokens per million words, respectively). All of the above seems to indicate, rather unsurprisingly, that indeed is preferred in argumentative discourse.

As for the second most common adverb in the data, i.e. clearly, its frequency in the corpus (386 tokens per million words) was similar to that noted by SimonVandenbergen and Aijmer (2007, pp. 201203) in the case of legal crossexaminations (300 tokens per million words). In other text categories, for instance in different types of academic writing, the frequency of clearly was much lower and it stood in the region of 100-150 tokens per million words (SimonVandenbergen and Aijmer 2007, pp. 201203). This seems to suggest, on the one hand, a connection between clearly and high-stake encounters, where tangible evidence and logical reasoning take centre stage and, on the other hand, its limited relevance in less challenging communicative settings.

Turning now to (not) necessarily, no comparisons can be made with SimonVandenbergen and Aijmer's (2007) data, since their study does not discuss the distribution of this item across different 
text types. With respect to of course, the last of the adverbs analyzed in the current study, several observations can however be made. While its frequency in the Opinions was relatively low (89 tokens per million words), in Simon-Vandenbergen and Aijmer's (2007, pp. 201-203) research of course proved to be the most commonly preferred adverb, whose frequency in spoken genres greatly exceeded that of all the other adverbs. Specifically, the frequency of of course in monologic demonstrations stood at 1,400 tokens per million words, in broadcast interviews at 1,200 tokens, in non-broadcast speeches at 1,150 tokens and in parliamentary debates at 1,100 tokens. In written genres, conversely, the frequency of of course was roughly half its frequency in spoken genres. It may then be cautiously posited that the preference of of course observed in spoken communication results from its status as politeness marker and the facesaving role it often performs (although, admittedly, it may operate as a marker of superiority, too). In the Opinions analyzed in this study, the need to stress solidarity or equality did not seem to be highly relevant and that is perhaps the reason why authority-oriented markers such as indeed or clearly were preferred over the solidarity-oriented of course. Notwithstanding the above observation, however, larger corpora would need to be investigated for these trends to be confirmed (or disproved) in different types of judicial opinions or judgments.

Another point worth raising is the distinction made in the current study between native and non-native discourse. Here again a caveat is in order: since the corpus is rather small and given the uneven distribution of Opinions between the individual Advocates General, the data do not necessarily reflect patterns in the use of modal adverbs which might be identified if more representative, balanced corpora of judicial opinions were examined. This research path seems, however, worth pursuing in subsequent studies on the construction of judicial argumentation by justices who are native and non-native speakers of English.

That said, what is more relevant to the discussion of the role of modal adverbs in the Opinions is their distribution within argumentative schemata. Although not quantitatively oriented, the study seems to suggest certain regularities or trends in the deployment of individual adverbs. For instance, indeed was found in the $A$ and indeed $B$ pattern, marking rhetorical addition. It was also identified in Concessive schemata, where it cued acknowledgments (i.e. moves signaling partial alignment with an opposing viewpoint) subsequently followed by the author's preferred arguments (i.e. counterclaims). In this context, indeed cooccurred with the emphatic do, which again increased the rhetorical force of the arguments advanced by the arguer.

The soundness of argumentation was also underlined by clearly and necessarily. In the case of these adverbs, nevertheless, no recurrent argumentative patterns emerged. What could be observed, however, was that while clearly was positionally mobile, occupying both sentence-initial and sentence-medial positions, necessarily never occurred sentence-initially, which indicates that its status as an epistemic marker is not at the same level as that of the remaining adverbs.

Last but not least, there were several occurrences of of course in acknowledgments, in which opposing views were backgrounded, only to be followed by the Advocate General's preferred (foregrounded) argument in the countermove. This strategy, it may be suggested, created the so-called "put-down effect" (Simon-Vandenbergen, White and Aijmer 2007), whereby the arguer on the one hand admits solidarity with the addressee (which could be paraphrased as yes, you are right), but on the other hand, he or she demonstrates superior (in his or her view) knowledge and puts forward the preferred claim. In the Opinions, counterclaims, given the formal register of judicial opinions, were signaled with the formal contrastive marker "however," rather than the less formal "but" (which nevertheless was used elsewhere in the Opinions).$^{18}$ It is also necessary to add that

\footnotetext{
18 Cf. Szczyrbak's (2016) data on the co-occurrence patterns with but and of course in spoken legal communication. As Szczyrbak's (2016) study reveals, in the adversarial trial selected for analysis, of course was the most frequent modal adverb to co-occur with but in Concessive sequences (with certainly being the second most frequent choice). Interestingly, in the claimant's and the witnesses' turns, of course was most frequent as a right collocate of but (i.e. it was found in post-but sequences ending with a weaker argumentative position or "backing down"), while in the turns of the judge and the counsel, of course was
} 
while in spoken communication, claims, acknowledgments, and counterclaims tend to be adjacent moves (or turns at talk), in the Opinions this was not always the case. As a result, individual moves stretched across larger segments of text and as such, they had to be interpreted in the larger argumentative frame.

Finally, it can be reiterated that - as the foregoing analysis has shown - modal adverbs of certainty are used as engagement devices which interact with "contradictory opinions, points of view, and value judgments" (Bakhtin 1981, p. 281). Seen in this way, they are found to "dialogue" with alternative standpoints or possible criticisms, thus constituting "interactional structures buried in singlesource narratives" (Edmondson, 2014, p. 79).

\section{Conclusion}

This article argues that the Advocates General at the ECJ use modal adverbs of certainty not only to express their attitudes towards (certainty of) knowledge but also to achieve particular rhetorical goals. The study suggests that some of these adverbs are common persuasive and argumentative devices used by justices to align with, or disalign from alternative viewpoints, whether actually articulated or only anticipated. In particular, the examination shows that in their judicial reasoning, the Advocates General tend to favor authorityoriented epistemic adverbs (indeed) as well as evidential adverbs referring to evidence (clearly) rather than, for instance, speech act adverbs, which were least frequently employed in the dataset analyzed. Another interesting phenomenon in judicial argumentation, it was found, is the rhetorical strategy of conceding (concessio), that is, "agreeing to disagree", involving the use of indeed and of course (the two adverbs being used chiefly to background alternative viewpoints) in argumentative schemata, and thus giving

more frequent as a left collocate of but (i.e. it was found in pre-but sequences signaling the upcoming disagreement or counterclaim). This seems to corroborate the findings reported here, showing the advocates' preference for the Yes, of course, however pattern, in which of course operates as a "precursor of disagreement" signaling the upcoming countermove. Evidently, the deployment of modal adverbs within argumentative schemata depends not only on the genre but also on the speaker's or writer's status in the interaction. more prominence to the arguments preferred by the Advocates General. 


\title{
References
}

AlJMER, K., 2007. Modal adverbs as discourse markers: A bilingual approach to the study of indeed. In: J. Rehbein, Ch. Hohenstein and L. Pietsch, eds. Connectivity in grammar and discourse. Amsterdam and Philadelphia: John Benjamins, pp. 329-344.

ANSCOMBRE, J.C. and DUCROT, O., 1983. L'argumentation dans la langue. Brussels: Pierre Mardaga.

BARTH-WEINGARTEN, D., 2003. Concession in spoken English. On the realisation of a discourse-pragmatic relation. Tübingen: Narr.

BAKHTIN, M.M., 1981. The dialogic imagination. Four essays by M.M. Bakhtin. Edited by M. Holquist. Translated by Caryl Emerson and Michael Holquist. Austin: University of Texas Press.

BIBER, D. et al., 1999. Longman grammar of spoken and written English. Harlow: Longman.

CHAFE, W.L., 1986. Evidentiality in English conversation and academic writing. In: W.L. Chafe and J. Nichols, eds. Evidentiality: The linguistic coding of epistemology. Norwood: Ablex, pp. 261-272.

COUPER-KUHLEN, E. and THOMPSON, S.A., 2000. Concessive patterns in conversation. In: E. Couper-Kuhlen and B. Kortmann, eds. Cause, condition, concession, contrast: Cognitive and discourse perspectives. Berlin and New York: Mouton de Gruyter, pp. 381-410.

EDMONDSON, W.J. 2014. The emergence of discourse analysis as a disciplinary field: philosophical, pedagogic and linguistic approaches. In: K.P. Schneider and A. Barron, eds. Pragmatics of discourse. Berlin and Boston: Mouton de Gruyter, pp. 65-95.

FETZER, A., 2014. Conceptualising discourse. In: K.P. Schneider and A. Barron, eds. Pragmatics of discourse. Berlin and Boston: Mouton de Gruyter, pp. 35-61 .

GEERAERTS, D., 2006. Prospects and problems of prototype theory. In: D. Geeraerts, ed. Cognitive linguistics: Basic readings. Berlin and New York: Mouton de Gruyter, pp. 141-167. HYLAND, K., 2005. Stance and engagement: a model of interaction in academic discourse.

Discourse Studies, vol. 7, no. 2, pp. 173-192.

QUINTILIAN, 1921-1933.The institutio oratoria of Quintilian. New York: Putnam's Sons.

SALMI-TOLONEN, T., 2005. Persuasion in judicial argumentation: The opinions of the Advocates General at the European Court of Justice. In: H. Halmari and T. Virtanen, eds. Persuasion across genres. A linguistic approach. Amsterdam and Philadelphia: John Benjamins, pp. 59-101.

SCHWENTER, S. and TRAUGOTT, E.C., 2000. Invoking scalarity: The development of in fact. Journal of Historical Pragmatics, vol. 1, pp. 7-25.

SIMON-VANDENBERGEN, A.M. and AIJMER, K., 2007. The semantic field of modal certainty. A corpus-based study of English adverbs. Berlin and New York: Mouton de Gruyter.

SIMON-VANDENBERGEN, A.M., WHITE, P. and AIJMER, K., 2007. Presupposition and 'takingfor-granted' in mass communicated political argument. An illustration from British, Flemish and Swedish political colloquy. In: A. Fetzer and G.E. Lauerbach, eds. Political discourse in the media. Amsterdam and Philadelphia: John Benjamins, pp. 31-74.

SZCZYRBAK, M., 2016. Concessive marking revisited: but in courtroom talk. Paper presented at $3^{\text {rd }}$ International Conference on Linguistic and Psycholinguistic Approaches to Text Structuring. València, Spain, 24-35 January.

WHITE, P., 2003. Beyond modality and hedging: A dialogic view of the language of intersubjective stance. Text, vol. 23, no. 2, pp. 259-284.

\author{
Author's address and contact details \\ Magdalena Szczyrbak, PhD. \\ Institute of English Studies \\ Jagiellonian University \\ al. Mickiewicza 9a \\ Kraków, 31-120 \\ Poland \\ E-mail: magdalena.szczyrbak@uj.edu.pl
}

